\title{
A Problem for the Unambitious View of Legal Normativity
}

\author{
Stefano Bertea ${ }^{1}$
}

\begin{abstract}
In this contribution, I discuss the so-called "unambitious view of legal normativity", as it is specifically theorised by Brian Bix. While I agree with Bix that legal normativity should not be assumed to be reducible by default to moral normativity, I will argue that the normativity of law cannot be qualified as a sui generis form of normativity. For, pace Bix, the quality of legal normativity is best understood as genuine. That is, the normative claims the law makes on its subjects do address the general practical question: What ought we to do?
\end{abstract}

Keywords: legal positivism, normativity, law, morality.

\section{Introduction}

Today legal theorists of different orientations and with diverse backgrounds agree that the task of elucidating the normativity of the law in general and the nature of such normativity in particular are key components of any ambitious research programme in jurisprudence. ${ }^{2}$ Brian Bix figures among them, since in his work he repeatedly engages with (multiple components of) the normativity of the law, by thus theorising a position that is both original and intriguing. ${ }^{3}$ Here I intend to specifically discuss a study, appeared in a previous issue of this journal, where Bix's own account of legal normativity is made to emerge progressively through the critical treatment of the conceptions put forward by Hans Kelsen and Herbert Hart. ${ }^{4}$ In such study, Bix $(2018,10)$ commits himself to (what he qualifies as) an "unambitious view of legal normativity", which is programmatically purported to secure an explanation of the normative components of the law that is coherent with the stance of legal positivism. Insofar as Bix's unambitious view of legal normativity can be shown to be tenable, then, we would be able to count on a framework that contributes, on the one hand, to advance our understanding of a fundamental dimension of the law-its normativity-and, on the other hand, to rescue a traditional school of law-legal positivismfrom a potentially unsettling criticism non-positivists recurrently make-the objection that legal positivism is conceptually unable to account for the normative dimension of the law.

In this contribution, I will claim that in his elegant and sophisticated theoretical proposal Bix makes a valuable point when he notices that legal normativity should not be

\footnotetext{
* This research was supported by a Deutsche Forschungsgemeinschaft Research Grant.

2 The task of explaining legal normativity is central to the following contemporary works, among many others: Hart (1982), Postema (1982), Raz (1994), Coleman (2001), Marmor (2001), Perry (2001), Alexy (2002), Marmor and Sarch (2015), and Green (2018). For a dissenting position see Enoch (2011).

${ }^{3}$ In particular, I should refer the reader to the claims defended in Bix (1996, 2006, 2012, 2015, and 2018).

4 The study I refer to is Bix (2018).
} 
assumed to be reducible by default to moral normativity. At the same time, I will observe, Bix's conclusion $(2018,10)$ that the normativity of the law is "a sui generis form of normativity" should be resisted, at least insofar as this conclusion is interpreted as meaning that the quality of legal normativity is (or just may be) less than genuine, or unqualified, to the effect that the validity of the normative claims the law makes on its subjects are confined to a given domain and thus refrain from addressing the practical question: What ought we to do?

\section{Legal Normativity as Genuine Normativity}

In my understanding Bix's unambitious view, as it applies to the explanation of the nature of legal normativity, consists of two basic tenets. ${ }^{5}$ First, it amounts to the statement that the law does not necessarily make moral claims on us and, by their nature, legal propositions cannot be equated to moral propositions (or, more generally, to proposition of a different, non-distinctively-legal kind). Secondly, the force of legal normativity, legal "oughts", legal standards, and legal reasons is (often) confined within a particular domain. As a result, legal normativity is best understood as a special subset of what is practically normative-a subset that does not necessarily carry direct connections and compete with other instantiations of practical normativity, such as moral normativity and prudential normativity. On this view, then, the normative realm is a fragmented territory inhabited by different forms of "ought" and reason. Those forms of "ought" and reason neither necessarily communicate one with another nor of necessity have any mutual influence. As a result, the "oughts" and reasons originating in any given specific subset of the normative cannot be assumed to be reducible to, or even just to be challengeable by, "oughts" and reasons stemming from the other subsets of the normative.

Now, the first fundamental claim substantiating Bix's unambitious view of legal normativity is, I think, largely tenable. No one is entitled to quickly and unreflectively presuppose that the law necessarily (or even possibly) makes moral claims on its subjects, issues categorical demands upon those living under its jurisdiction, and requires them to act without regard to their self-interests. That the law makes such claims, issues such demands and puts forward such requirements is a robust theoretical position that need be analytically argued for, as opposed to being a platitude about the normativity of the law and so a proposition one is legitimated to take for granted.

By contrast, I find the second fundamental claim shaping Bix's unambitious view of legal normativity objectionable. In order to start appreciating the problem with that further

\footnotetext{
${ }^{5}$ See in particular Bix $(2018,7-8)$.
} 
claim, one should notice that it is deeply anchored in the contention that normative deliberation on practical matters is not a unified practice, but rather an internally divided and possibly even radically disjointed affair. On this account, normative practical reasoning "is often confined within a particular domain", to the effect that "one can have "legal reasons' that can differ from not only 'moral reasons' and 'prudential reasons', but also 'etiquette reasons', 'fashion reasons', or 'chess reasons'"' (Bix 2017, 7). This compartmentalised picture of normative practical reasoning strikes me as at least partly questionable. While I agree that certain normative practices-such as etiquette, fashion and games-typically make merely domain-specific claims on those subject to them, ${ }^{6}$ in my view we are entitled to neither maintain that all normative practices operate so nor include the law among the normative practices making domain-specific claims. For there is a crucial, conceptual difference that sets the law apart from the practices that can be regarded as paradigmatically making domain-specific claims, such as the ones Bix refers to-etiquette, fashion and (chess-like) games. And this difference prevents us from concluding that legal normativity is a sector-bound kind of normativity in the same sense and to the same extent in which the normativity of, say, etiquette, fashion or games are. The difference at stake here can be concisely stated as follows: etiquette, fashion and games are circumscribed practices by their own nature; by contrast, the law constitutively concerns general and essential dimensions of our existence and so purportedly impacts on the reasoning about how we ought to act period. Which is why the practical claims the law makes cannot be compared with the practical claims etiquette, fashion and games make.

To elaborate on this point, the conceptual discontinuity between the law, on the one hand, and paradigmatically domain-specific practices such as etiquette, fashion and games, on the other, derives from the fact that legal institutions purport to regulate (nearly) every aspect of our lives. There is hardly any dimension of our activities that does not fall under the jurisdiction of the law. Such jurisdiction is then both deep and comprehensive: the boundaries of the law nearly coincide with the limits of our lives and its standards govern a legal subject's existence from (before) birth to (after) death. The only option we have, if we wish to renounce our legal subjectivity, may consist in resolving to leave our country for good (since most legal systems stretch their jurisdiction across an entire country or even beyond). As can be appreciated, that is not something we can decide as blithely as we might decide to depart from some rule of etiquette, refuse to conform to the dictates of fashion, or walk away from a match of some game in case it occurs to us that we do not like the standards of etiquette, fashion and games. To put it otherwise, no etiquette, fashion or

\footnotetext{
${ }^{6}$ In this regard, the reader may want to refer to Scanlon (2014).
} 
game is so pervasive in its scope or so deep in the concerns it deals with as the law is. In fact, etiquette, fashion and games extend only so far into our practical lives and their range is likewise limited. The practices etiquette, fashion and game consist of can therefore be bracketed, since they typically occupy the interstitial spaces between genuinely practical normative practices. Likewise, even if we have devoted ourselves fully to the enterprise of mastering the rules of some etiquette generally practiced in a given social group, keeping up with the rapidly changing patterns of fashion, or playing a given game we find intriguing, and are emotionally invested in such activities, ordinarily there still are sizable and important chunks of our life experience that remain untouched by etiquette, fashion and games. For etiquette, fashion and games are constitutively domain-specific practices, namely, practices framed by standards that confine them within a specific sector of our practical life.

Hence, contrary to what Bix's unambitious view of legal normativity seems to presuppose, the difference between the law, on the one hand, and constitutively domainspecific practices, on the other, is a profound difference. Crucially, this difference should be understood as conceptual. I qualify the difference as conceptual, since it is ultimately owed to the previously mentioned systematic scope of the law-namely, its programmatically being a practice established to regulate fundamental human concerns that are pervasive in our life and characterise it in depth. This near ubiquity of the law-its seeping into almost every aspect of everyone's life-is something that cannot be disregarded in offering an account of legal normativity. For, by virtue of regulating life at large, rather than some specific and overall peripheral dimension of our existence, the "oughts", reasons and norms of the law overlap with those of practical rationality at large, with which the "oughts", reasons and norms of the law are also meant to compete in determining what ought to be done. As a consequence of this dimension, the claims the law makes on us are coextensive with those practical rationality makes-they are, in other terms, genuine, or general, claims vis-à-vis narrow and domain-specific claims. And likewise similar is the mode of practical deliberation these claims have us engage in, for they are all meant to guide and justify action. On the same ground, it should be concluded that these claims all share the same kind of normativity, a normativity that is genuinely practical. Legal "oughts", reasons and norms should, in other terms, be understood as having real, or unqualified, normative force: they make claims on our practical deliberation at large and put these claims forward as rationally justified.

This genuinely practical character conceptually distinguishes legal "oughts", reasons and norms from the requirements engendered by etiquette, fashion and games. Requirements of this latter kind are only purported to govern moves within a well-delimited 
sphere clearly separated from the rest of one's practical existence and deliberation. Therefore, they do not ordinarily partake of our practical reasoning in general. This conceptual discontinuity-ultimately traceable to the different breadth and depth of the practices at issue (the law, on the one hand, etiquette, fashion and games, on the other)means that we cannot explain the nature of the normativity associated with those practices in the same way. That is to say, the "oughts", reasons and norms associated with the existence of constitutively domain-specific practices, such as etiquette, fashion and games, can well be conceptualised as specialised "oughts", reasons and norms-they can well be understood as standards that hold in a narrow sense only and so are conceptually discontinuous with genuinely binding standards. This is not how the "oughts", reasons and norms generated by the law can be conceptualised though. Since legal "oughts", reasons and norms are incumbent on one's whole life-they cover much more ground and address much more fundamental issues than any etiquette- fashion- and game- generated requirement-they are genuinely practical demands that are affected by, and exercise influence on, the likewise genuinely directives set out by practical rationality. This radical diversity, which sets the "oughts", reasons and standards associated with the existence of constitutively domain-specific practices apart from the "oughts", reasons and standards that concern our practical deliberation at large, supports the likewise deep-seated different nature of this typology of "oughts", reasons and standards when compared with the kind of "oughts", reasons and standards of the law. Since the law is so pervasive and concerns essential practical matters, the "oughts", reasons and norms we have under the law cannot be adequately described as merely sectorial and narrowly focused; they are, by contrast, deeply connected with our practical existence at large and therefore genuine in kind.

In conclusion, the law is an all-encompassing practice bound up with fundamental aspects of our practical lives; and the same features transfer to the "oughts", reasons and standards we incur under the law. Legal "oughts", reasons and standards are comprehensive and their bindingness is genuine-they are not "oughts", reasons and standards associated with merely domain-specific practices-covering much the same ground as the "oughts", reasons and standards that issue from our engagement in practical rationality and the practice practical rationality informs, so much so that they compete with the latter. And, just as the standards of practical rationality are deep and pervasive, so are the norms of the law with the attendant "oughts", reasons and norms. These "oughts", reasons and norms are, thus, binding in a sense in which the "oughts", reasons and norms generated by constitutively domain-specific practices such as etiquette, fashion and games are not: the normative nature of these latter "oughts", reasons and norms is such that they 
rarely, if ever, clash with the broader and unqualified claims the law and practical rationality make on action. From which it follows that Bix's unambitious view based on the statement that the normativity of the law is continuous with the normativity of constitutively domainspecific practices is misleading, giving us a distorted picture of what legal "oughts", reasons and norms are.

\section{Conclusion}

In this contribution, I set out to discuss Bix's account of the nature of legal normativity. I argued that such account is meritorious, insofar as it consists in the statement that the legal "ought" cannot be simply assumed to necessarily be moral in quality. However, I also rejected Bix's further statement that, on the same basis, legal normativity is best understood as a particular-domain and separate-sector kind of normativity, vis-à-vis an unqualified, or rationality-related, sort of normativity. Such further statement implies that legal "oughts", reasons and norms have no direct bearing on the question What ought we to do? Likewise, it means that legal standards operate in the same way in which the rules associated with narrowly focused practices such as etiquette, fashion, and games work. Those claims, I argued, are questionable. In consideration of its comprehensive and fundamental concern-legal provisions cover essential aspects of people's lives and govern relationships that are inseparable from our practical existence at large-the law directly and extensively engages with general practical issues. As a result, qua an enterprise that is deeply entrenched in virtually all the dimensions of our existence, the law makes claims on us that are purportedly general and genuine, as opposed to being sectorial and domainspecific.

To be sure, the quality of the normativity of the law may turn out not to be moral, as Bix contends; but, pace Bix, it is unqualifiedly practical-legal reasons are integrated with standard reasons for action, be they prudential reasons, moral reasons, or other kinds of encompassing reasons for action. For legal reasons occupy the same space inhabited by standard practical reasons, and legal "oughts" are real practical "oughts", which cannot be insulated from general practical "oughts". By the same token, legal norms are fundamentally distinct from, and irreducible to, the norms generated by etiquette, fashion and games. It is on those bases that I deemed the unambitious view of legal normativity to constitute a theoretically objectionable account of the kind of "oughts", reasons and norms engendered by the law.

\section{Bibliography}


Alexy, Robert (2002). The Argument from Injustice, Oxford: Oxford University Press

Bix, Brian (1996). "Jules Coleman, Legal Positivism, and Legal Authority", Quinnipiac Law Review, 16: 241-54

Bix, Brian (2006). "Legal Positivism and 'Explaining' Legal Normativity and Authority", American Philosophical Association Newsletter, 5: 5-9

Bix, Brian (2012). "The Nature of Law and Reasons for Action", Problema, 5: 399-415

Bix, B. 2015. "Rules and Normativity in Law", in Tomasz Gizbert-Studnicki and others (eds.), Problems of Normativity, Rules and Rule Following, Springer, 2015, 125-46

Bix, Brian (2018). "Kelsen, Hart and Legal Normativity", Revus, 1-17

Coleman, Jules (2001). The Practice of Principle. Oxford: Oxford University Press

Enoch, David (2011). Reason-Giving and the Law. In L. Green \& B. Leiter (eds.), Oxford Studies in Philosophy of Law, vol. I (pp. 1-38). Oxford: Oxford University Press.

Green, Leslie (2018). "Legal Positivism", The Stanford Encyclopedia of Philosophy (Spring 2018 Edition), Edward N. Zalta (ed.), forthcoming URL = <https://plato.stanford.edu/archives/spr2018/entries/legal-positivism/>.

Hart, Herbert (1982). "Commands and Authoritative Legal Reasons". In Essays on Bentham. Oxford: Oxford University Press, 243-

Marmor, Andrei (2001). Positive Law and Objective Values. Oxford: Oxford University Press Marmor, Andrei and Sarch, Alexander (2015). "The Nature of Law", The Stanford Encyclopedia of Philosophy (Fall 2015 Edition), Edward N. Zalta (ed.), URL = https://plato.stanford.edu/archives/fall2015/entries/lawphil-nature/

Perry, Stephen (2001). "Hart's Methodological Positivism". In J. Coleman (ed.), Hart's Postscript. Oxford: Oxford University Press, 311-54

Postema, Gerald (1982). "Coordination and Convention at the Foundation of the Law", Journal of Legal Studies, 11: 165-203

Raz, Joseph (1994). "The Problem about the Nature of Law". In Ethics in the Public Domain, Oxford, Clarendon, 195-209

Scanlon, Thomas M. (2014). Being Realistic About Reasons. Oxford: Oxford University Press. 